\title{
Use Triticale Grains Replacing of Corn in Broiler Chick Diets and their Effect on Some Quality Characteristics of Breast Meat
}

\author{
Nadia N. A. AL-Hajo ${ }^{1}$, Layla A. F. AL-Janabi ${ }^{2}$, Firas M. H. AL-Khalani ${ }^{3}$, Imade A. AL-Ani ${ }^{4}$ \\ ${ }^{1}$ Dept. of Animal Resource / College of Agriculture / University of Baghdad, Iraq \\ ${ }^{2}$ Dept. of Food Science \& Biotechnology / College of Agriculture / University of Baghdad, Iraq \\ ${ }^{3,4}$ State Board for Agric. Res., Ministry of Agriculture
}

\begin{abstract}
The present study was conducted using 1120 Ross chicks to determine meat quality of partial substitution of corn with triticale grain (Feedar) one-day-old unsexed chicks were randomly distributed as a complete randomized block design into eight equal treatments, each with four replicates (35 chicks/replicate). The chicks were reared on wood shavings in pens. The area of each pen was $3 m 2(2 \mathrm{mX1.5m)}$. Treatments were diet 1: T1 (The control ,without triticale) ; T2: (25\% triticale replacement of corn ), T 3: (50\% triticale replacement of corn ); T4: (75\% triticale replacement of corn ); T5: (100\% tritical) ; T6: (Replacement all the energy of corn with triticale ) ; $T 7$ (use 100\% triticale with enzyme) ; T8 : (Replacement all the energy of corn with triticale and enzyme) . All birds were fed ad libitum on the same starting (0-21 d) and growing (22-42 d) diets. The chicks sexed in 28 day. At 42 d of age, broilers were slaughtered and cutting the carcasses breast to estimate some quality characteristics of meat. Sensory evaluation (Tenderness, Juiciness, Flavor, Texture, Overall acceptance and General appearance) were significantly higher $(P<0.05)$ in $T_{7}$ group compared with other groups, and were significantly increased $(P<0.05)$ in physical dissection and decreased in thawing and cooking loss when compared with another treatment. Tenderness, juiciness and flavor and texture were not effected by sexes, while males has got the highest score for overall acceptance and general appearance compared to females.Males increased in physical dissection and thawing loss and decreased in cooking loss. In conclusion, the current study suggested that $T_{7}$ (100\% triticale with enzyme) had good quality characteristics of broiler breast meat .
\end{abstract}

Keywords: Broiler breast meat, Sensory evaluation, Physical evaluation, Tritical

\section{Introduction}

Triticale is an alternative cereal grain that is a hybrid of wheat and rye(Korver et al.,2004). These species were crossed with the intention of producing a grain with the feeding characteristics of wheat and the winter hardiness, drought and disease resistance of rye (Boros, 1999). Triticale has an excellent productivity potential (Gatel et al., 1985; Vohr et al., 1991) and a greater flexibility to adapt to difficult agronomic conditions than wheat (Gatel et al., 1985).However, early triticale varieties had poor feeding characteristics relative to wheat, and triticale developed a reputation of being unsuitable in poultry diets ( Fernandez and McGinnis, 1974; Wilson and McNab,1975). One of the outstanding features of triticale has traditionally been its protein content. Gatel et al. (1985) reported that with an equal crude protein content, triticale is richer in lysine than wheat, comparable to wheat in threonine and sulfur amino acid contents but slightly poorer in tryptophan than wheat. Salmon (1984) found that triticale contained more lysine, arginine, aspartic acid, and alanine than wheat.

In recent years, the poultry industry has experienced an unrivalled rate of growth. This can be attributed to poultry having relatively low production costs, high nutritional values, rapid growth rates, and a great number of furtherprocessed products (Barbut, 2002). Boneless breast meat is the most popular meat in the American household and Iraqi market. Increasing demand by consumers has led the industry to find methods for increasing production of boneless meat without negatively affecting overall consumer acceptance and ensuring product uniformity.Changing consumer demand in the Iraq has influenced the markets for all types of meat.

Increasing muscle mass (especially breast meat yield)or growth rates has been the focus of chicken genetic selection in meat lines for decades (Dransfield and Sosnicki, 1999; Havenstein et al., 2003)

The purpose of the present study was to compare the meat quality of broiler chicks feed diets containing triticale at different replacement levels of corn .

Although not investigated in the present study, the effects of modern cultivars of triticale on meat quality characteristics may be an interesting area for future research.

\section{Materials and Methods}

A total of 1120 one-day-old unsexed Ross TM, in poultry research station /Animal Department /State Board of Agriculture / Ministry of Agriculture, chicks were randomly distributed as a complete randomized block design into eight equal treatments, each with four replicates (35 chicks/ replicate). The chicks were reared on wood shavings in pens . The area of each pen was $3 \mathrm{~m} 2(2 \mathrm{mX} 1.5 \mathrm{~m})$. Treatments were diet 1: T1 (The control, without triticale ) ; T2: $(25 \%$ triticale replacement of corn ), T 3: (50\% triticale replacement of corn ); T4: (75\% triticale replacement of cornR ); T5: (100\% tritical) ; T6: (Replacement all the energy of corn with triticale ) ; T7 (use 100\% triticale with 


\section{International Journal of Science and Research (IJSR) \\ ISSN (Online): 2319-7064 \\ Index Copernicus Value (2013): 6.14 | Impact Factor (2014): 5.611}

enzyme ) ; T8 : (Replacement all the energy of corn with triticale and enzyme ). All birds were fed ad libitum on the same starting (0-21 d) and growing (22-42 d) diets .The chicks sexed in 28 day. At $42 \mathrm{~d}$ of age, broilers were slaughtered and cutting the carcasses breast to estimate some quality characteristics of meat.

The degree of sensory evaluation of flavor, tenderness, juiciness and overall acceptance of cooked meat by boiling determined according to Lee et al. (1997). A 7-point hedonic scale (7-like extremely, 1-dislike extremely) was used to evaluate the following attributes. Ten staff members of the college of agriculture and graduate students most of whom had participated in previous consumer panels work as panelists, were given the details about this panel and we do a primary panel before the essential test which we adapted in this study. We depending the standard point to control on varieties which may effect the degree of panel: Time of the test in 11 O'clock (A.M.), degree of cooking temperature, time between cooking and test, drinking water in $25 \mathrm{oC}$ between the test and other, finally the size of the pieces which we tested.

Physical dissection was estimate according to AL-Hajo ( 2005 ) ,Thawing loss was estimate according to Young and Lyon ( 1997 ), while cooking loss was estimate according to Rasmussein and Mast(1989).

The data were analyzed using Complete Randomized Design and Multiple Regression. The calculation was preformed by the SAS package programmers (SAS, 2001). LSD test was used to determine significant differences.

\section{Results and Discussion}

Tenderness is a major quality determinant and also an important sensory characteristic of meat . Meat tenderness mainly depends on muscle fiber size, collagen content and solubility and water and lipid content(Baeza et al. ,2013).Also,many factors can affect meat tenderness; especially, postmortem(PM) deboning time can have a large influence (Cavitt et al.,2005). Lyon and Lyon (1997), using broiler fillets deboned 2, 6, and $24 \mathrm{~h}$ postmortem, reported Pearson correlation (r) values more than 0.9 for sensory descriptive attributes hardness and cohesiveness.

Result in table (1) illustrate that $\mathrm{T}_{2}$ and $\mathrm{T}_{7}$ got the highest $(\mathrm{P}<0.05)$ degrees of sensory qualities of the tenderness, which ranged from tender to very tender, and did not differ significantly for the treatment $\mathrm{T}_{1}$, and there were not significant differences between another treatment. Given that in the study carried out by Fanatico et al. (2007) the birds used for the evaluation were different genetic strains and raised for different days, the differences in shear force among the different weights of cooked fillets could result from the genetic lines, bird ages, or the interaction of genetic lines and bird ages. Abdullah and Matarneh (2010)attributed the increase in shear force values of breast meat from the heavy broiler carcasses to an increasing amount of connective tissues in the meat.

Table 1: Effect of feeding different ratios of triticale on sensor evaluation of broiler breast meat

\begin{tabular}{|c|c|c|c|c|c|c|}
\hline Treatment & Tenderness & Juiciness & Flavour & Texture & Overall acceptance & General appearance \\
\hline $\mathrm{T}_{1}$ & $5.14 \mathrm{ab}$ & $5.57 \mathrm{ab}$ & $5.36 \mathrm{~b}$ & $\mathrm{a} 5.57$ & $5.36 \mathrm{a}$ & $5.56 \mathrm{a}$ \\
\hline $\mathrm{T}_{2}$ & $5.86 \mathrm{a}$ & $5.29 \mathrm{~b}$ & $5.36 \mathrm{~b}$ & $2.57 \mathrm{c}$ & $4.14 \mathrm{~b}$ & $4.79 \mathrm{cb}$ \\
\hline $\mathrm{T}_{3}$ & $3.21 \mathrm{c}$ & $3.57 \mathrm{c}$ & $4.79 \mathrm{bc}$ & $4.64 \mathrm{ab}$ & $4.04 \mathrm{~b}$ & $3.57 \mathrm{~b}$ \\
\hline $\mathrm{T}_{4}$ & $4.21 \mathrm{bc}$ & $4.21 \mathrm{c}$ & $4.92 \mathrm{bc}$ & $2.50 \mathrm{c}$ & $2.43 \mathrm{c}$ & $2.29 \mathrm{c}$ \\
\hline $\mathrm{T}_{5}$ & $3.86 \mathrm{c}$ & $3.64 \mathrm{c}$ & $4.50 \mathrm{c}$ & $2.64 \mathrm{c}$ & $2.43 \mathrm{c}$ & $2.14 \mathrm{c}$ \\
\hline $\mathrm{T}_{6}$ & $4.00 \mathrm{c}$ & $3.79 \mathrm{c}$ & $4.5 \mathrm{c}$ & $2.71 \mathrm{c}$ & $3.14 \mathrm{c}$ & $2.29 \mathrm{c}$ \\
\hline $\mathrm{T}_{7}$ & $6.14 \mathrm{a}$ & $6.21 \mathrm{a}$ & $6.14 \mathrm{a}$ & $5.43 \mathrm{a}$ & $5.50 \mathrm{a}$ & $5.57 \mathrm{a}$ \\
\hline $\mathrm{T}_{8}$ & $4.07 \mathrm{c}$ & $4.14 \mathrm{c}$ & $4.50 \mathrm{c}$ & $3.14 \mathrm{~b}$ & $4.71 \mathrm{bc}$ & $4.43 \mathrm{cb}$ \\
\hline
\end{tabular}

Dissimilar superscripts at the same coloum means significant $(\mathrm{P}<0.05)$

Savage et al. (1987) investigated the physical and sensory quality of cooked meat from aged breeder turkey toms fed diets containing varying amounts of triticale ,they found that tenderness increased with increasing amounts of dietary triticale as determined by observations of Warner-Bratzler shear values $(\mathrm{P}<0.05)$ and sensory panel scores $(\mathrm{P}<0.05)$. Thus, they reported that tenderness of cooked turkey meat from aged breeders can be influenced by diet. Odland et al. (1955) reported a similar finding in market aged turkeys.

Data in Table ( 1) indicates that $\mathrm{T}_{7}$ had a higher $(\mathrm{P}<0.05)$ degrees of sensory qualities (Juiciness) ranged from juiciness to very juiciness, and there were no significant differences between $T_{1}$ and $T_{2}$ which obtained score between medium juiciness to juiciness. There were no significant differences between the other treatments. Savage et al. (1987) investigated the physical and sensory quality of cooked meat from aged breeder turkey toms fed diets containing varying amounts of triticale, they found that sensory juiciness increased as the amount of dietary triticale increased.

The flavor (Table 1), $\mathrm{T}_{7}$ rang from strong flavor to very strong, no significant differences between $\mathrm{T}_{1}$ and $\mathrm{T}_{2}$, while there were no significant differences between another treatment. Abdullah and Matarneh (2010) suggest that breast fillet weight may influence both sensory flavor and texture quality of meat. Savage et al. (1987) investigated the physical and sensory quality of cooked meat from aged breeder turkey toms fed diets containing varying amounts of triticale, They reported that no significant effects of triticale in diet were noted for panel scores of the triticale diets when compared with results in control fed male.

Zhuang and Savage (2012) found that the cooked light fillets have a negative flavor ,or more cardboardy, compared with the heavier fillets , and the medium fillets taste less sour than either the lighter or the heavier fillets, the difference is only 0.2 points in a 0 to 15 intensity scale. 


\section{International Journal of Science and Research (IJSR) \\ ISSN (Online): 2319-7064 \\ Index Copernicus Value (2013): 6.14 | Impact Factor (2014): 5.611}

Texture are illustrated in Table (1), $\mathrm{T}_{1}$ and $\mathrm{T}_{7}$ got the highest $(\mathrm{P}<0.05)$ degree of sensory qualities, ranging from soft texture to very soft texture, and there were no significant differences between the other treatments. Without any explanation of the causes for the texture differences, Pragati et al. (2007) concluded that use of broilers of heavy weight ( $>2000 \mathrm{~g}$ live weight) would benefit the quality of furtherprocessed chicken products. These results demonstrate that both chicken growth rates and body weight affect the sensory quality of cooked breast meat

Shear force has been widely used as an indicator for sensory texture quality attributes tenderness, hardness, and cohesiveness for both red meat and poultry breast fillets due to the strong and significant correlations between WB shear force values and the sensory evaluation scores (Dikeman et al., 2005; Xiong et al., 2006).

Johnson and Eason (1988) observed that growth of broiler chickens was similar whether triticale or wheat was the cereal source in diets that contained $50 \%$ cereal and were equalized for nutrient content. Similarly, Vieira et al.(1995) found that the graded inclusion of triticale up to $40 \%$ (substituted for corn) had no negative effect on weight gain or final weight of broilers. In those studies, the limited replacement of the main cereal grain might have hidden any negative effects of triticale. Complete replacement of corn with triticale in the diets of White Leghorn pullets did not affect BW (Lesson and Summers, 1987).

Charalambous et al. (1986) observed that carcass yield, carcass plus edible giblets yield, and dressing percentage were higher in birds fed corn or corn-triticale diets than in broilers fed a diet with triticale as the only cereal grain .And thus effected the sensory evaluation score

Overall acceptance (table 1), $\mathrm{T}, 7$ was also accepted in high $(\mathrm{P}<0.05)$ degree of score and did not differ significantly from the $T_{1}$. And there were no significant differences between the other treatments. Texture and flavor are important sensory characteristics of meat, which can strongly influence overall consumer acceptance and choice of meat, Fanatico et al. (2005) reported that either growth rates or live bird weights affected the sensory flavor intensity or acceptance of breast meat. General appearance illustrated in ( Table 1) we can observed that $\mathrm{T}_{1}$, and $\mathrm{T}$, had a significant increased, ranged from medium to be desired appearance.

The genotypes, slaughter ages, or further processing techniques by themselves can significantly affect sensory quality and functionality of chicken breast meat(Northcutt, 2006; Fanatico et al. ,2006, 2007 ; Alvarado and McKee, 2007; Saha et al., 2009).

Although such small differences perceived in a sensory descriptive evaluation may not be important to overall consumer acceptance of cooked chicken breast meat. Tenderness, juiciness and flavor and texture (Figure 1) were not effected by sexes, while males has got the highest score for overall acceptance and general appearance compared to female.

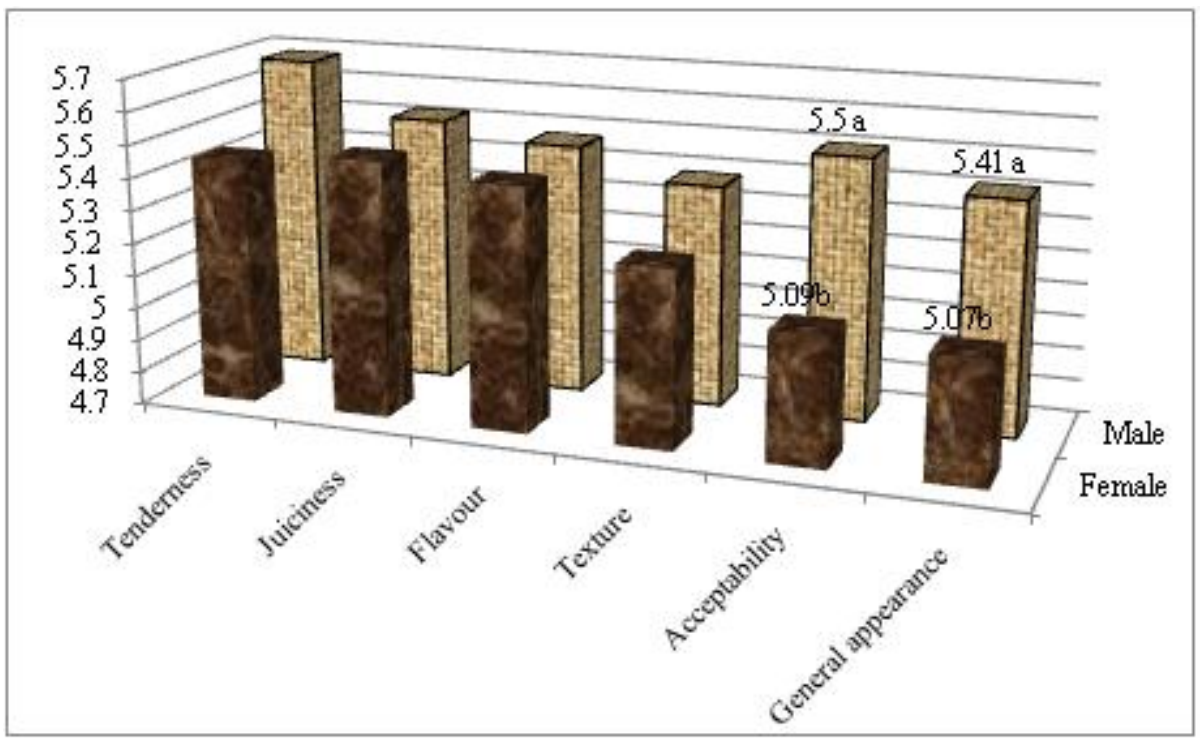

Figure 1: Effect of sex on sensory evaluation of broiler breast meat feeding different ratio of triticale

We can notes that treatment $\mathrm{T}_{7}$ got the highest degree of sensory evaluation, while the treatments $\mathrm{T}_{6}$ and $\mathrm{T}_{5}$ had a lower score of sensory evaluation. There is no published study that directly addresses how Triticale affects sensory quality or profiles of cooked chicken meat in peer-reviewed journals.

Chicken breast meat contains less connective tissue than beef (Zorba and Kurt, 2006).Protein characteristics and physicochemical properties of red and white meat were different from each other (Zorba and Kurt, 2006, 2008). The ratio of myofibrillar proteins in the protein composition related to structure of protein matrix and that explain the differences between breast and thigh meat.

Physical dissection (Table 2)we found that $\mathrm{T}_{4}$ and $\mathrm{T}_{7}$ was significantly higher $(\mathrm{P}<0.05)$ compared within each treatment, whereas $\mathrm{T}_{5}$ and $\mathrm{T}_{6}$ decreased significant $(\mathrm{P}<$ $0.05)$ when compared within each treatment, and there were no significant differences between another treatment.

\section{Volume 5 Issue 2, February 2016}




\section{International Journal of Science and Research (IJSR) \\ ISSN (Online): 2319-7064}

Index Copernicus Value (2013): 6.14 | Impact Factor (2014): 5.611

Thawing loss is shown in Table (2), $\mathrm{T}_{7}$ were significantly decreased and did not differ from $\mathrm{T}_{2}$ and $\mathrm{T}_{3}$, and there were no significant differences when compared within each treatment .And we can notes that the treatments $\mathrm{T}_{5}$ and $\mathrm{T}_{6}$ got the highest percentage of thawing loss. Rammouz et al.(2004) said that the effect of $\mathrm{pH}_{\mathrm{u}}$ on drip loss is a (charge effect) as $\mathrm{pH}$ decreases, the repulsion forces between the myofibrils decrease because $\mathrm{pH}$ is approaching the isoelectric point of myofibrillar protein ,thus reducing the space available for water in the cell. Indeed, muscle glycogen would bind 2 to $4 \mathrm{~g}$ of water per $\mathrm{g}$ of muscle (Greenleaf et al.,1969).This could lead to an excess of free water relative to the protein network available to hold it, thus inducing an extra release of water during cooking (Rammouz et al.,2004).

Table (2) :Effect of feeding different ratios of triticale on physical parameters of broiler breast meat.

\begin{tabular}{|c|c|c|c|}
\hline Treatment & Physical Dissection & Thawing Loss & Cooking Loss \\
\hline $\mathrm{T}_{1}$ & $66.13 \mathrm{c}$ & $2.04 \mathrm{~b}$ & $15.86 \mathrm{~d}$ \\
\hline $\mathrm{T}_{2}$ & $73.81 \mathrm{~b}$ & $2.83 \mathrm{~b}$ & $16.89 \mathrm{~d}$ \\
\hline $\mathrm{T}_{3}$ & $72.74 \mathrm{~b}$ & $2.99 \mathrm{~b}$ & $22.17 \mathrm{~b}$ \\
\hline $\mathrm{T}_{4}$ & $80.88 \mathrm{a}$ & $3.11 \mathrm{a}$ & $20.13 \mathrm{c}$ \\
\hline $\mathrm{T}_{5}$ & $62.49 \mathrm{~d}$ & $3.14 \mathrm{a}$ & $23.62 \mathrm{a}$ \\
\hline $\mathrm{T}_{6}$ & $62.46 \mathrm{~d}$ & $3.05 \mathrm{a}$ & $23.82 \mathrm{a}$ \\
\hline $\mathrm{T}_{7}$ & $83.07 \mathrm{a}$ & $2.16 \mathrm{c}$ & $16.66 \mathrm{~d}$ \\
\hline $\mathrm{T}_{8}$ & $76.34 \mathrm{~b}$ & $3.14 \mathrm{a}$ & $21.66 \mathrm{~b}$ \\
\hline
\end{tabular}

Dissimilar superscripts at the same coloum means significant $(\mathrm{P}<0.05)$

Treatment $\mathrm{T}>$ has the lower $(\mathrm{P}<0.05)$ percentage of Cooking loss(Table 2) and did not differ significantly with treatment $\mathrm{T}_{2}$ and $\mathrm{T}_{1}$ while $\mathrm{T}_{5}$ and $\mathrm{T}_{6}$ was increased significant $(\mathrm{P}<0.05)$ in the percentage cooking loss compared within each treatment . AL-Fayad et al. (2011) reported that the increase in skin fat deposition reduce cooking loss,the fat protect the fluid within the muscle and prevent it from loss. Savage et al. (1987) investigated the physical and sensory quality of cooked meat from aged breeder turkey toms fed diets containing varying amounts of triticale ,they reported that cooking loss and drip loss declined as the amount of dietary triticale increased. Promeyrat et al.( 2010) found that because of the denaturation of protein during heating, the fibers shrink, water distribution within the myofibril matrix changes and this results in cooking loss .

Figure (2) shown the effect of sexes on physical dissection of broiler breast meat, males increased $(\mathrm{P}<0.05)$ in weight of physical dissection compared with females and that because of increase the weight of males compared with females (AL-Fayad et al., 2011). AL-Hajo (2007) found that males broiler have higher physical dissection than female. And males also were higher in thawing loss (Fig.3) compared with females, while females were a significant $(\mathrm{P}<0.05)$ increased in cooking loss (Fig.4) compared with males because female superiority in increasing fat deposition comparable with male because of the continuous movement of male which leads to energy consumption more than females and decreased fat deposition (AL-Fayad et al., 2011).

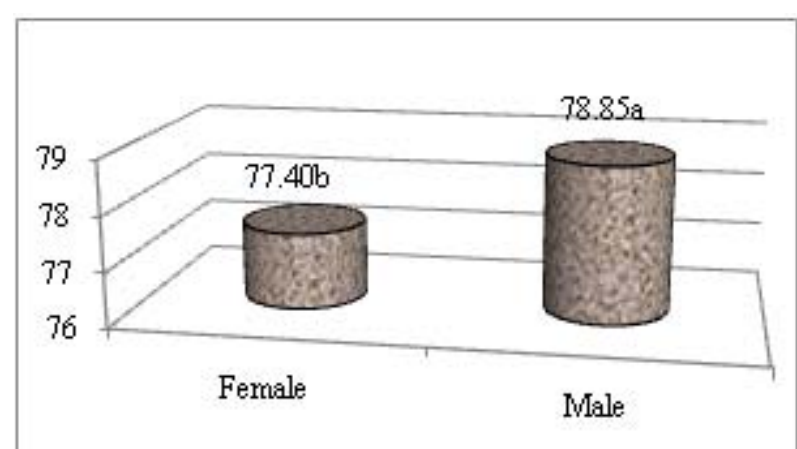

Figure 2: Effect of sex on physical dissection of broiler breast meat feeding different ratio of triticale

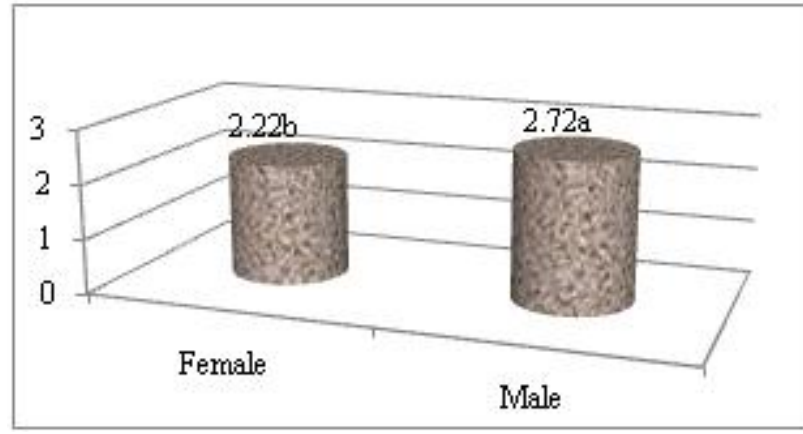

Figure 3: Effect of sex on thawing loss of broiler breast meat feeding different ratio of triticale

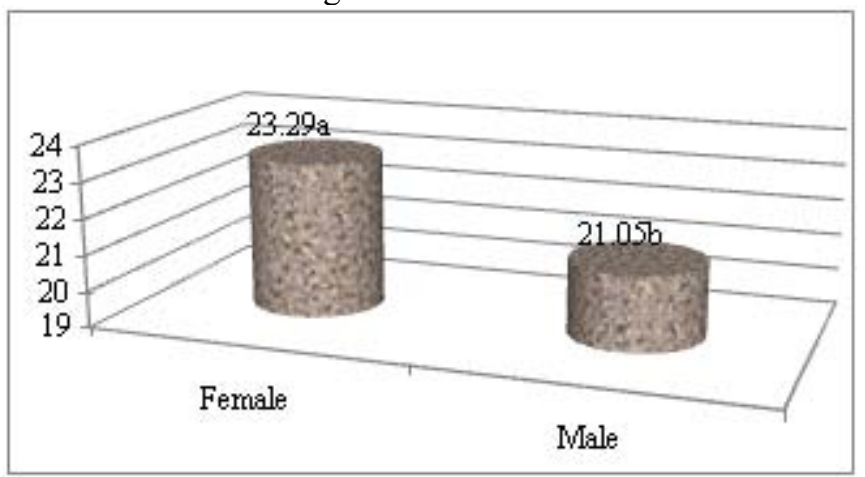

Figure 4: Effect of sex on cooking loss of broiler breast meat feeding different ratio of triticale

This finding is in contrast with the result published by Fanatico et al. (2005) who found that female broilers had more drip loss than did male.

Effect of alternative feed grains should be added to the factors of an animal's acceptance and economic performance that are already use to determine the final salvage value of age bird carcasses (Savage et al.1987). The chemical composition of triticale is sufficiently different from corn and soybean (Lorenz,1974) that chicken meat characteristics can be altered by feeding diets containing this feed stuff .

\section{References}

[1] Abdullah, A. Y., and S. K. Matarneh. 2010. Broiler performance and the effects of carcass weight, broiler sex, and postchill carcass aging duration on breast fillet quality characteristics. J. Appl.Poult. Res. 19:46-58.

[2] Al-Hajo,Nadia N.A.,2005. The Effect of Age on Broiler Performance, Meat Properties, and the Economic Feasibility of Broilers Projects. Thesis ,A 


\section{International Journal of Science and Research (IJSR) \\ ISSN (Online): 2319-7064 \\ Index Copernicus Value (2013): 6.14 | Impact Factor (2014): 5.611}

dissertation Submitted to the Council of the College of Agriculture At the University of Baghdad,Iraq.

[3] AL-Fayad,H.A.,Naji,S.A.,AL-

Hajo,Nadia,N.A.,2011.Poultry product and technology .A book, published in university of Baghdad, Iraq.

[4] Alvarado, C., and S. McKee. 2007. Marination to improve functional properties and safety of poultry meat. J. Appl. Poult.Res. 16:113-120 .

[5] Barbut, S. (2002) Poultry products - formulations and gelation, in: BARBUT, S. (Ed.), Poultry Products Processing: An Industry Guide, pp. 446 (New York, NY, CRC Press).(Leidahl, 2006.

[6] Baeza,E. P. Chartrin, V. Gigaudi, S. Tauty, K. Meteau, M. Lessire and C. Berri.2013 . Effects of dietary enrichment with $\mathrm{n}-3$ fatty acids on the quality of raw and processed breast meat of high and low growth rate chickens. British Poultry Science, Vol. 54, No. 2, 190198.

[7] Boros, D. 1999. Influence of $\mathrm{R}$ genome on the nutritional value of triticale for broiler chicks. Anim. Feed Sci. Technol.76:219-226.

[8] Cavitt, L. C., J. F. Meullenet, R. K. Gandhapuneni, G. W. Youm, and C. M. Owens. 2005. Rigor development and meat quality of large and small broilers and the use of Allo-Kramer shear, needle puncture, and razor blade shear to measure texture. Poult. Sci.84:113-118.

[9] Charalambous, K., A. Koumas, and S. Economides. 1986. The effect of triticale grain on the performance of chicks from birth to nine weeks of age. Tech. Bull. Agric. Res. Inst. 79:1-7.

[10] Dransfield, E., and A. A. Sosnicki. 1999. Relationship between muscle growth and poultry meat quality. Poult. Sci. 78:743-746.

[11]Dikeman, M. E., E. J. Pollak, Z. Zhang, D. W. Moser, C. A. Gill,and E. A. Dressler. 2005. Phenotypic ranges and relationships among carcass and meat palatability traits for fourteen cattle breeds, and heritabilities and expected progeny differences for

[12] Warner-Bratzler shear force in three beef cattle breeds. J. Anim.Sci. 83:2461-2467.

[13] Fanatico, A. C., L. C. Cavitt, P. B. Pillai, J. L. Emmert, and C.M. Owens. 2005. Evaluation of slower-growing broiler genotypes grown with and without outdoor access: Meat quality. Poult.Sci. 84:1785-1790.

[14] Fanatico, A. C., P. B. Pillai, L. C. Cavitt, J. L. Emmert, J. F.Meullenet, and C. M. Owens. 2006. Evaluation of slower-growing broiler genotypes grown with and without outdoor access: Sensory attributes. Poult. Sci. 85:337-343.

[15] Fanatico, A. C., P. B. Pillai, J. L. Emmert, E. E. Gbur, J. F. Meullenet,and C. M. Owens. 2007. Sensory attributes of slow- and fast-growing chicken genotypes raised indoors or with outdoor access. Poult. Sci. 86:24412449.

[16]Fernandez, R., and J. McGinnis. 1974. Nutritive value of triticale for young chicks and effect of different amino acid supplements on growth. Poult. Sci. 53:4753.

[17] Havenstein, G. B., P. R. Ferket, and M. A. Qureshi. 2003. Carcass composition and yield of 1957 vs. 2001 broilers when fed representative1957 and 2001 broiler diets. Poult. Sci. 82:1509-1518.
[18] Gatel, F., O. Lavorel, J. Fekete, F.Grosjean and J. Castaing. 1985. Feeding value of triticale for

[19] monogastrics: weaned piglets,growing-finishing pigs and broilers. In:Bernard, M., S. Bernard (Eds.).Genetics and Breeding of Triticale. Emir. J. Food Agric. 2008.20(2):41-50

[20] http://www.cfa.uaeu.ac.ae/research/ejfa.htm

[21] Greenleaf,J.K.,K.E.Olsson, and B.Saltin .1969.Muscle glycogen and its significance for the water content of the body .Acta physiol.Scand.Suppl. 30:86 (Abstract )(sited by Rammouz et al.2004).

[22] Johnson, R., and P. Eason. 1988. Evaluation of triticale for use in diets for meat-type chickens. J. Sci. Food Agric. 42:95-108.

[23] Korver ,D. R,*,1 M. J. Zuidhof, $\dagger$ and K. R. Lawes. 2004. Performance Characteristics and Economic Comparison of Broiler ChickensFed Wheat- and Triticale-Based Diets

[24] Poultry Science 83:716-725.

[25] Lee, T. G., S.K. Williams, D. Slaon, and R. Little, 1997. Development and evaluation of a chicken breakfast sausage manufactured with mechanically deboning chicken meat. Poultry Sci., 76:415-421.

[26]Leeson, S., and J. D. Summers. 1987. Response of White Leghorns to diets containing ground or whole triticale. Can. J. Anim.Sci. 67:583-585.

[27] Lorenz,K., 1974.The history ,development ,and utilization of triticale .Page 175-288 in:CRC Critical Reviews in Food Technology .Vol.5.Chem.Rubber Co.Press, Cleveland, $\mathrm{OH}$.

[28] Lyon, B. G., and C. E. Lyon. 1997. Sensory descriptive profile relationships to shear values of deboned poultry. J. Food Sci.62:885-897.

[29] Northcutt, J. K. 2006. Factors affecting poultry meat quality. Accessed Sep. 2, 2011. http://en.engormix.com/MA-poultryindustry/

[30] meat-industry/articles/factors-affecting-poultrymeatt1218/471-p0.htm.

[31] Odland,L.M.,H.L.Mayfield, and L.Page,1955.Influence on palatability of certain combinations, fish soluble and a vitamin B12 -Aureomcin supplementation in poultry rations.Poultry Sci.34:822 - 822-831.

[32] Pragati, H., N. Kondaiah, A. S. R. Anjaneyulu, and P. Saikia. 2007. Meat yields and sensory quality of products from broilers of three live weight groups. Indian J. Anim. Sci. 77:613-615.

[33]PROMEYRAT, A., GATELLIER, P., LEBRET, B., KAJAK-SIEMASZKO, K.,AUBRY, L. \& SANTÉLHOUTELLIER, V. (2010) Evaluation of protein aggregation in cooked meat. Food Chemistry, 121:412417.

[34] Rammouz,R.E.,R.Babile,X.Fernandez.2004.Effect of ultimate $\mathrm{pH}$ on the physicochemical and

[35] And biochemical characteristics of turkey breast muscle showing normal rate of Poultry Sci.83:1750-1757.

postmortem $\mathrm{pH}$ fall.

[36] Rasmussein, A.L. and M.G. Mast, 1989. Effect of feed withdrawal on composition and quality of broiler meat. Poultry Sci., 68:1109-1113.

[37] Saha, A., A. V. S. Perumalla, Y. Lee, J. F. Meullenet, and C. M.Owens. 2009. Tenderness, moistness, and flavor of pre- and postrigor marinated broiler breast 


\section{International Journal of Science and Research (IJSR) \\ ISSN (Online): 2319-7064}

Index Copernicus Value (2013): 6.14 | Impact Factor (2014): 5.611

fillets evaluated by consumer sensory panel. Poult. Sci. $88: 1250-1256$

[38] Salmon,R.E.,1984. True metabolizable energy and amino acid composition of wheat and triticale and their comparative performance in turkey starter diets. Poultry Science, 63:1664-1666.

[39] Statistical Analysis Sistem(SAS), 2001. SAS User's Guide: Statistics ( version 6.0) SAS Inst. Inc. Cary, NC, USA.

[40] Savage, T. F., Z. A. Holmes, A. H. Nilipour, and H. S. Nakaue.1987. Evaluation of cooked breast meat from male breeder turkeys fed diets containing varying amounts of triticale,

[41] variety Flora. Poult. Sci. 66:450-452.

[42] Vieira, S. L., A. M. Penz, A. M. Kessler, and E. V. Catellan, Jr.1995. A nutritional evaluation of triticale in broiler diets. J.Appl. Poult. Res. 4:352-355.

[43] Vohra, P., S. Bersch, C. Q. Qualset, and R. Baker. 1991. Triticale:Analternative cereal grain in broiler starter diets. Calif. AgZric.45:34-37.

[44] Wilson, B. J., and J. M. McNab. 1975. The nutritive value of triticale and rye in broiler diets containing field beans (vicia Faba L.). Br. Poult. Sci. 16:17-22.

[45] Xiong, R., L. C. Cavitt, J. F. Meullenet, and C. M. Owens. 2006.Comparison of Allo-Kramer, WarnerBratzler and razor blade shears for predicting sensory tenderness of broiler breast meat. J. Texture Stud. 37:179-199.

[46] Young, L.L., and C.E. Lyon, 1997. Effect of electrical stimulation in combination with calcium chloride or sodium chloride treatments at constantion icon moisture binding and textural quality of early harvested breast fillets.Poultry.,Sci.,76:1446-1449.

[47]Zhuang,H. and E.M.Savage . 2012.Effect of fillet weight on sensory descriptive and texture profiles of broiler breast meat .Poultry Sci. 91:1659-1702.

[48]Zorba, O., and Ş. Kurt. 2006. Optimization of emulsion characteristics of beef, chicken and turkey meat mixtures in model system using mixture design. Meat Sci. 73:611-618.

[49]Zorba, O., and Ş. Kurt. 2008. The effects of different plant oils on some emulsion properties of beef, chicken and turkey meats. Int.J. Food Sci. Technol. 43:229-236. 